\title{
Perbandingan Hasil Belajar Peserta Didik Menggunakan Problem Based Learning Dengan Contextual Teaching and Learning Dalam Pelajaran Geografi
}

\author{
(Studi Quasi-Experimental Design di Kelas X SMAN 5 Banda Aceh)
}

\author{
Novia Zalmita $^{1} *$, Novra Rizkia ${ }^{2}$ \\ ${ }^{1,2}$ Universitas Syiah Kuala \\ Email: *noviazalmita@unsyiah.ac.id,nvrarzkia@gmail.com
}

Dikirim : 21 Januari 2020

Diterima: 31 Maret 2020

\begin{abstract}
Abstrak: Praktik belajar mengajar saat ini sering ditemukan permasalahan seperti penggunaan model yang masih minim dan kurang sesuai dengan karakteristik peserta didik. Umumnya guru mengajar hanya menggunakan model pembelajaran konvensional, sedangkan Kurikulum 2013 menuntut peserta didik untuk dapat berpikir tingkat tinggi. Hal tersebut tentunya dapat dicapai dengan menerapkan model pembelajaran seperti Problem Based Learning dan Contextual Teaching and Learning dalam proses pembelajaran. Penelitian ini bertujuan membandingkan hasil belajar kedua model tersebut pada mata pelajaran Geografi Kelas X di SMAN 5 Banda Aceh. Metode penelitian menggunakan pendekatan kuantitatif dengan jenis penelitian eksperimen yaitu eksperimen semu (quasi-experimental) dengan asumsi awal hasil belajar yang diajarkan menggunakan Problem Based Learning lebih baik dibandingkan dengan yang diajarkan menggunakan Contextual Teaching and Learning. Populasi dalam penelitian ini adalah seluruh peserta didik kelas X di SMAN 5 Banda Aceh. Penarikan sampel menggunakan purposive sampling dengan mempertimbangkan kemampuan awal peserta didik adalah sama. Sampel yang diambil sebanyak dua kelas yang berjumlah 46 peserta didik. Teknik pengujian hipotesis menggunakan uji statistik non parametrik menurut Mann-Whitney (Uji U) dengan menggunakan uji $Z$ karena sampel $>20$. Hasil yang diperoleh dari hasil $U j i \mathrm{U}$ yakni $Z_{\text {hitung }}=5,81$ dan pada taraf signifikansi 5\%, diperoleh $Z_{\text {tabel }}=1$,65. Jadi diperoleh $Z_{\text {hitung }}>Z_{\text {tabel }}$ sehingga terima $H_{a}$. Dengan demikian, dapat disimpulkan hasil belajar peserta didik yang diajarkan dengan Problem Based Learning (PBL) lebih baik dibandingkan dengan Contextual Teaching and Learning (CTL) pada pelajaran Geografi Kelas X di SMAN 5 Banda Aceh.
\end{abstract}

Kata Kunci: Perbandingan, Problem Based Learning (PBL), Contextual Teaching and Learning (CTL), Hasil belajar, quasi-experimental design

\begin{abstract}
Teaching and learning practices today are often found problems such as the use of models that are still minimal and not in accordance with the characteristics of students. Generally teachers teach using only conventional learning models, while the Kurikulum 2013 requires students to be able to think at a high level. This can certainly be achieved by applying learning models such as Problem Based Learning and Contextual Teaching and Learning in the learning process. This study aims to compare the learning outcomes of the two models in Class X Geography in SMAN 5 Banda Aceh. The research method uses a quantitative approach to the type of experimental research that is quasi-experimental design with the initial assumption that learning outcomes taught using Problem Based Learning are better than those taught using Contextual Teaching and Learning. The population in this study were all grade $\mathrm{X}$ students at SMAN 5 Banda Aceh. Sampling using a purposive sampling by considering the initial ability of students is the same. Samples were taken as many as two classes totaling 46 students. Hypothesis testing techniques using non-parametric statistical tests according to Mann-Whitney (U test) using the $\mathrm{Z}$ test because the sample> 20. The results obtained from the results of the $\mathrm{U}$ Test namely Zhitung $=5.81$ and at a significance level of 5\%, obtained Ztable $=1.65$. So it is obtained Zhitung $>$ Ztabel so accept Ha. Thus, it can be concluded that learning outcomes of students taught with Problem Based Learning (PBL) are better than Contextual Teaching and Learning (CTL) in Geography Class X in SMAN 5 Banda Aceh.
\end{abstract}


Keywords: Comparison, Problem Based Learning (PBL), Contextual Teaching and Learning (CTL), Learning Outcomes, quasi-experimental design

\section{Pendahuluan}

Pendidikan merupakan salah satu komponen penting dalam meningkatkan potensi sumber daya manusia suatu bangsa sehingga dapat menjadikan suatu negara menjadi lebih maju. Keberhasilan pendidikan dapat dilihat dari hasil belajar peserta didik selama proses pendidikan berlangsung. Oleh karena itu demi meningkatkan hasil belajar peserta didik, guru dituntut untuk mampu mengatur proses belajar mengajar yang menarik. Praktik belajar mengajar saat ini sering ditemukan permasalahan seperti penggunaan model yang masih minim dan kurang sesuai dengan karakteristik peserta didik. Umumnya guru mengajar hanya menggunakan model pembelajaran konvensional, sedangkan Kurikulum 2013 menuntut peserta didik untuk dapat berpikir tingkat tinggi seperti keterampilan berpikir kritis, kreatif dan problem solving (pemecahan masalah).

Model pembelajaran PBL dan CTL dapat menjadi contoh model pembelajaran yang bisa diterapkan dalam proses pembelajaran. SMAN 5 Banda Aceh adalah salah satu sekolah di Banda Aceh yang bisa diterapkan kedua model pembelajaran tersebut. Dari hasil observasi awal, peserta didik masih kurang berminat terhadap proses pembelajaran geografi sehingga proses pembelajaran cenderung pasif.

PBL merupakan pendekatan pembelajaran yang dapat meningkatkan keterampilan pemecahan masalah sebagai cara untuk mencari dan mendapatkan informasi (Pratiwi, 2012; Tadjer, 2020). PBL memiliki fokus bagaimana cara peserta didik memecahkan masalah secara kritis, kemudian dilanjutkan dengan mengindentifikasi permasalahan tersebut untuk meningkatkan kemampuan penalaran mereka (Kilroy, 2004). Selain itu model pembelajaran ini dapat memperkaya eksplorasi masalah dalam tahapan mengambilan keputusan (Wormley etc, 2019). Berdasarkan hasil penelitian Gunantara, dkk (2014:9), PBL dapat meningkatkan kemampuan pemecahan masalah peserta didik. PBL tidak mengacu pada metode pembelajaran tertentu, namun tergantung pada desain metode pendidikan yang digunakan dan keterampilan guru. Dengan demikian model ini sangat dianjurkan untuk digunakan oleh guru dalam proses mentransfer ilmu kepada peserta didik di sekolah.

Dalam rancangan Kurikulum 2013 selain PBL, Contextual Teaching and Learning (CTL) juga merupakan model yang sangat direkomendasikan untuk diaplikasikan dalam proses pembelajaran. CTL merupakan model pembelajaran dengan strategi pembelajaran yang tidak hanya memberikan materi tertulis, namun peserta didik dituntut untuk bisa mengaitkan materi pembelajaran kondisi faktual di masyarakat (Kadir, 2013). Berdasarkan penelitian yang dilakukan oleh Arfodi (2016) diperoleh hasil bahwa penerapan model CTL dapat meningkatkan peran serta belajar peserta didik dalam mata pelajaran gambar konstruksi bangunan.

Dari kedua model tersebut tentu keduanya memiliki keunggulan masing-masing. Untuk melihat efesiensi kedua model tersebut dalam meningkatkan hasil belajar peserta didik penulis berkeinginan untuk melakukan penelitian eksperimental untuk mengetahui perbandingan hasil belajar peserta didik yang diajarkan dengan Problem Based Learning (PBL) dengan Contextual Teaching and Learning (CTL) pada mata pelajaran Geografi Kelas X di SMAN 5 Banda Aceh.

\section{Metode Penelitian}

Penelitian ini menggunakan pendekatan kuantitatif dengan jenis penelitian eksperimen. Penelitian eksperimen mengambil desain eksperimen semu (quasi-experimental design). Dalam desain ini kelompok eksperimen maupun kelompok kontrol tidak dipilih secara random. Sehingga dalam pengambilan sampel menggunakan teknik purposive sampling dengan mempertimbangkan kemampuan awal peserta didik adalah sama.

\section{Pengumpulan Data}

Dalam memperoleh data, ada beberapa teknik yang digunakan. Masing-masing teknik tersebut memiliki fungsinya tersendiri sesuai dengan tujuan penelitian, jenis data serta keadaan subjek penelitian. 
Instrumen yang digunakan adalah studi literatur dan tes hasil belajar. Studi literatur dimaksudkan untuk mendapatkan sejumlah data berupa teori dan konsep yang berkaitan dengan permasalahan penelitian. Teori dan konsep ini akan digunakan sebagai pedoman untuk memperkuat informasi atau sebagai landasan pemikiran penelitian ini. Sedangkan tes digunakan untuk mengukur hasil belajar peserta didik. Hasil belajar ini akan digunakan untuk menjawab hipotesis penelitian. Teknik tes yang digunakan adalah tes objektif bentuk pilihan ganda. Teknik tes ini dirasa sangat tepat untuk mengukur sejauh mana hasil belajar peserta didik setelah diberlakukan suatu treatment/perlakuan.

\section{Analisis Data}

Analisis data menggunakan analisis kuantitatif dengan statistik. Statistik yang digunakan adalah statistik inferensial dimana berfungsi untuk menganalisis data sampel dan hasilnya berlaku pula untuk populasi (Sugiyono, 2010). Tahapan statistik yang digunakan adalah uji homogenitas (uji varians), uji normalitas dan uji hipotesis penelitian. Uji homogenitas (uji varians) dan uji normalitas tersebut dilakukan sebagai syarat untuk menggunakan statistik parametrik dalam menguji hipotesis penelitian. Uji homogenitas bertujuan untuk melihat varians data relatif sama atau tidak. Adapun rumus homogenitas yang dipakai yakni rumus Uji Fisher (Sugiyono, 2017). Sedangkan uji normalitas bertujuan melihat apakah data dari hasil penelitian berdistribusi normal atau tidak. Adapun rumus normalitas yang digunakan yakni Rumus Chi Kuadrat.

Apabila hasil pengujian memenuhi asumsi data normal dan homogen, maka statistik parametrik menggunakan rumus uji-t dapat dilanjutkan, namun apabila asumsi data tidak berdistribusi normal dan/atau tidak homogen, maka uji yang digunakan yakni statistik non parametrik menurut Mann-Whitney (U test).

\section{Hasil dan Pembahasan}

Teknik analisis data yang digunakan menggunakan analisis kuantitatif. Data yang digunakan dalam penelitian ini antara lain data post-test. Adapun gambaran dari data post-test dari kelas eksperimen dan kelas kontrol dapat dilihat pada Tabel 1.

Tabel 1. Data Post Test Kelas Eksperimen dan Kelas Kontrol

\begin{tabular}{cccc}
\hline \multicolumn{2}{c}{ Kelas Eksperimen } & \multicolumn{2}{c}{ Kelas Kontrol } \\
\hline Max & 90 & Mak & 89 \\
\hline Min & 55 & Min & 65 \\
\hline
\end{tabular}

Sumber : Hasil Penelitian, 2019

Dari Tabel tersebut dapat dilihat bahwa nilai maksimal dan nilai minimal data post-test kelas eksperimen dan kelas kontrol memiliki nilai yang berbeda yaitu 90 dan 55, sedangkan nilai maksimal dan nilai minimal kelas kontrol adalah 89 dan 65.

Langkah berikutnya yang dilakukan yakni menghitung varians atau menguji homogenitas dari kedua kelas dengan menggunakan rumus Fisher. Adapun ringkasan dari perhitungan uji homogenitas dapat dilihat pada Tabel 3 .

Tabel 2. Hasil Perhitungan Uji Homogenitas Kelas Eksperimen dan Kelas Kontrol

\begin{tabular}{cccc}
\hline Kelas & F $_{\text {hitung }}$ & $\mathbf{F}_{\text {tabel }}$ & Kesimpulan \\
\hline Eksperimen & 2,00 & 2,05 & Data bersifat homogen \\
\hline Kontrol & & & \\
\hline
\end{tabular}

Sumber : Hasil Penelitian, 2019

Kriteria uji yang digunakan pada uji homogenitas yakni apabila $\mathrm{F}_{\text {hitung }}<\mathrm{F}_{\text {tabel, }}$, maka terima $\mathrm{H}_{0}$ yang artinya data bersifat homogen. Berdasarkan Tabel 2, dapat dilihat bahwa $F_{\text {hitung }}$ bernilai 2,00. $\mathrm{F}_{\text {tabel }}$ 
bernilai 2,05. Dari nilai tersebut dapat dilihat bahwa nilai $\mathrm{F}_{\text {hitung }}<\mathrm{F}_{\text {tabel }}$ yang artinya terima $\mathrm{H}_{0}$. Dengan demikian dapat disimpulkan bahwa terima data kelas eksperimen I dan kelas eksperimen II bersifat homogen atau memiliki varians yang sama. Selanjutnya ringkasan hasil perhitungan normalitas dari kedua kelas dapat dilihat pada Tabel 3.

Tabel 3. Hasil Perhitungan Uji Normalitas Kelas Eksperimen dan Kelas Kontrol

\begin{tabular}{|c|c|c|c|}
\hline Kelas & $x^{2}$ hitung & $x^{2}$ tabel & Kesimpulan \\
\hline Eksperimen & 15,81 & \multirow{2}{*}{11,07} & Berdistribusi Normal \\
\hline Kontrol & 6,34 & & Tidak Berdistribusi Normal \\
\hline
\end{tabular}

Sumber : Hasil Penelitian, 2019

Kriteria uji yang digunakan dalam pengujian normalitas data yakni apabila $x^{2}{ }_{\text {hitung }}<x^{2}$ tabel maka

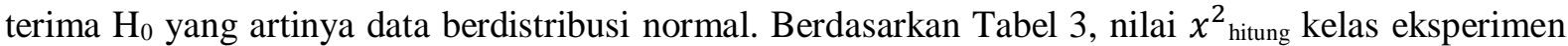
yakni 15,81 dan nilai $x^{2}$ hitung kelas kontrol yakni 6,34. Nilai $x^{2}$ tabel $=11,07$. Bedasarkan kriteria uji, data pada kelas eksperimen tidak berdistribusi normal atau tolak $\mathrm{H}_{0}$ dikarenakan nilai $x^{2}{ }_{\text {hitung }}>x^{2}$ tabel, sedangkan data pada kelas kontrol berdistribusi normal atau terima $\mathrm{H}_{0}$ dikarenakan nilai $x^{2}{ }_{\text {hitung }}<x^{2}{ }_{\text {tabel }}$. Oleh sebab itu, untuk pengujian hipotesis di uji menggunakan rumus statistik non parametrik $\mathrm{U}$ test menurut Mann-Whitney.

Pengujian hipotesis $U$ test menurut Mann-Whitney diawali dengan merangkingkan seluruh data post test dari nilai terendah ke nilai tertinggi. Jenis data yang digunakan dalam uji ini yakni data berskala ordinal. Sampel pada penelitian ini berjumlah $>20$, sehingga rumus yang digunakan yakni rumus Z. Adapun hasil dari perhitungan uji hipotesis U test menurut Mann-Whitney diperoleh hasil $Z_{\text {hitung }}=5,81$. Untuk menentukan $Z$ Tabel dengan uji satu pihak pada taraf signifikansi $5 \%$ yakni $\alpha / 1=$ $0,05 / 1=0,05$. Luas kurva $F(z)=0,5-0,05=0,4500$. Dari hasil perhitungan tersebut, didapatkan koordinat $Z_{\text {tabel }}=1,65$. Jadi berdasarkan hipotesis yang diajukan, dapat disimpulkan bahwa $Z_{\text {hitung }}>Z_{\text {tabel }}$ sehingga terima $\mathrm{H}_{\mathrm{a}}$ yang berarti hasil belajar yang diajarkan dengan menggunakan model Problem Based Learning lebih baik dibandingkan dengan hasil belajar yang diajarkan dengan menggunakan model Contextual Teaching and Learning.

Berdasarkan hasil penelitian, Problem Based Learning lebih baik dibandingkan Contextual Teaching and Learning disebabkan model pembelajaran PBL lebih menuntut peserta didik aktif untuk memecahkan permasalahan. Terlihat dari proses pembelajaran dimana peserta didik lebih aktif dan tertarik terhadap materi pembelajaran karena mereka mencari tahu sendiri kenapa suatu fenomena terjadi sehingga memancing mereka untuk berfikir kritis. Hal tersebut tentunya dapat meningkatkan hasil belajar karena peserta didik terlibat langsung untuk mencari tahu sehingga materi pembelajaran akan lebih mudah diserap dan diingat.

Hasil penelitian tersebut sesuai dengan hasil penelitian yang dilakukan oleh Gunantara, dkk (2014:9) bahwa model PBL bisa meningkatkan kemampuan pemecahan masalah peserta didik. Hasil penelitian lainnya menunjukkan hal yang sama bahwa nilai keberhasilan pada proses pembelajaran PBL lebih tinggi dibandingkan dengan nilai keberhasilan belajar CTL (Arfodi, 2016:189). Hasil yang sama pula menunjukkan bahwa model pembelajaran PBL berpengaruh terhadap keterampilan berpikir kreatif pesera didik pada mata pelajaran Geografi kelas X di SMA Negeri 2 Bandung (Zalmita, 2015:8).

Beberapa hasil penelitian tersebut di atas cukup menguatkan hipotesis yang diajukan oleh penulis bahwa model Problem Based Learning (PBL) lebih baik dibandingkan dengan model Contextual Teaching and Learning (CTL) pada materi teori pembentukan bumi dan bentukan lahan hasil pergerakan lempeng tektonik di kelas X SMAN 5 Banda Aceh, sehingga dapat disimpulkan bahwa model pembelajaran PBL dapat menjadi salah satu pilihan model pembelajaran yang dapat digunakan pada materi Teori Pembentukan Bumi dan Bentukan Lahan Hasil Pergerakan Lempeng Tektonik kelas $\mathrm{X}$.

\section{Kesimpulan}


Tujuan dari penelitian ini adalah melihat perbandingan antara hasil belajar peserta didik antara model pembelajaran Problem Based Learning dengan model pembelajaran Contextual Teaching and Learning di Kelas X SMA Negeri 5 Banda Aceh. Berdasarkan hasil uji hipotesis menggunakan uji Mann Whitney, pada taraf signifikansi $5 \%$ dengan dk 44 didapatkan nilai $Z_{\text {tabel }}=1,65$, sedangkan nilai $Z_{\text {hitung }}$ $=5,81$. Maka dapat disimpulkan bahwa nilai $Z_{\text {hitung }}>Z_{\text {tabel }}$ sehingga sesuai dengan kriteria uji hipotesis $\mathrm{H}_{\mathrm{a}}$ diterima yang artinya, hasil belajar peserta didik yang diajarkan dengan menggunakan model pembelajaran PBL lebih baik daripada hasil belajar peserta didik yang diajarkan dengan model pembelajaran CTL pada materi geografi dikelas X SMAN 5 Banda Aceh.

\section{Ucapan Terimakasih}

Ucapan terimakasi kepada kepala sekolah, guru dan peserta didik SMAN 5 Banda Aceh yang telah memberikan izin dan berkontribusi dalam penelitian ini serta kepada kerabat dosen Jurusan Pendidikan Geografi Fakultas Keguruan dan Ilmu Pendidikan Universitas Syah Kuala atas dukungan berupa moril sehingga penelitian ini terlaksana dengan baik.

\section{Daftar Rujukan}

Arfodi, Agil. 2016. Penerapan Model Pembelajaran Contextual Teaching and Learning (CTL) Untuk Meningkatkan Hasil Belajar Siswa Pada Mata Pelajaran Gambar Konstruksi Bangunan Kelas XI SMK Negeri 5 Surabaya. Jurnal Kajian Pendidikan Teknik Bangunan Universitas Negeri Surabaya. 2(2), Hal:172-190.

Gunantara, Gd. dkk. 2014. Penerapan Model Pembelajaran Problem Based Learning untuk Meningkatkan Kemampuan Pemecahan Masalah Matematika Peserta didik Kelas V. Jurnal Mimbar PGSD Universitas Pendidikan Ganesha. 2(1), Hal: 1-10.

Kadir, Abdul. 2013. Konsep Pembelajaran Kontekstual di Sekolah. Jurnal Dinamika Ilmu. 13(3), Hal: 17-38.

Kilroy D.A. 2004. Problem Based Learning. Emergency Medicine Journal. 21, pp. 411-413. doi: 10.1136/emj.2003.012435

Pratiwi, Yenni, Putri. 2012. Pengaruh Model Pembelajaran Berbasis Masalah Terhadap Keterampilan berpikir Kreatif Peserta Didik Pada Mata Pelajaran Geografi Di SMAN 2 Bandung. Jurnal Pendidikan Geografi. 15(1), Hal: 1-8.

Sugiyono. 2017. Statistik untuk Penelitian. Bandung: Alfabeta

---. 2018. Metode Penelitian Luantitatif, Kualitatif dan R\&D. Bandung: Alfabeta

Tadjer, H., Lafifi, Y., \& Seridi-Bouchelaghem, H. (2020). A New Approach for Assessing Learners in an Online Problem Based Learning Environment. In I. Management Association (Ed.), Learning and Performance Assessment: Concepts, Methodologies, Tools, and Applications (pp. 307-324). Hershey, PA: IGI Global. doi:10.4018/978-1-7998-0420-8.ch016

Zalmita, Novia. 2015. Pengaruh Model Pembelajaran Berbasis Masalah Terhadap Keterampilan berpikir Kreatif Peserta Didik Pada Mata Pelajaran Geografi Di SMAN 2 Bandung. Jurnal Pendidikan Geografi. 15(1), Hal: 1-8.

Wormley, Michelle E., Tovin, Melissa M., Lusardi, M., \& Wilson, S. (2019) Students' perspectives of core value development in a modified problem-based learning program. Physiotherapy Theory and Practice. 35:11, pp. 1061-1077, doi: 10.1080/09593985.2018.1469707 